\title{
Interpretation of the Religious Policy of Autocracy in the XIX - Early XX Senturies under Paradigm Change
}

\author{
Zakish T. Sadvokassova1 \\ Altaiy I. Orazbayeva ${ }^{1}$ \\ Aigul M. Sadykova² \\ ${ }^{1}$ L.N. Gumilyov Eurasian National University, 010008, Pushkin st. 11, Astana, Kazakhstan, Dr.(History), Professor; \\ Email: tungatar_k@mail.ru; altaiy_orazbaeva@mail.ru \\ 2 Faculty of Philology and History, Pavlodar State Pedagogical Institute, Mira street 60, Pavlodar, Kazakhstan;
}

Doi:10.5901/mjss.2015.v6n5s1p516

Email: aygulsadyk@mail.ru

\begin{abstract}
The article is written on the basis of scientific researches of the Soviet and modern historians both from the CIS-countries and abroad. The problem attracts attention and is of scientific interest due to the fact that modern approaches of scientists of the post-Soviet countries in the study of the religious policy of the Russian empire in the national regions differ from those of the preceding period. The current researchers, while writing their works, use and introduce into scientific circulation documentary materials from archives and rare libraries' collections, which in the Soviet times were "unnoticed". Pressing of the Soviet ideological machine did not allow scientists to give an objective assessment of individual historical events. Works of scientists of the capitalist camp were not available as "the bourgeois methodology" could cause great harm to the scientific researches of the Soviet historians whose "methodological basis was the Marxist-Leninist doctrine and the documents of the Party and government". The object is the research on the colonial policy of autocracy in the religious life of the non-Russian peoples. The purpose of the article is to highlight the impact of changes at the turn of the $X X-X X I$ centuries associated with the collapse of the Soviet empire and the formation of independent states on the process and the results of historical researches in the postSoviet republics.
\end{abstract}

Keywords: imperial policy, methodological approaches, historians, research, study, problems, spiritual life.

\section{Introduction}

Almost a quarter of a century ago the state called the Union of the Soviet Socialist Republics which caused mixed reactions in the world left the political arena. For example, some experienced towards it the feeling close to hatred, others expressed respect, the third showed purely mercantile interest expecting payment for "the loyalty to socialist ideals". Of course, in terms of ideological confrontation capitalist countries did not experience warm feelings for the Soviet Union. "Help" of the Soviet Union to the states which have liberated from colonial oppression and took the course of building socialism was reviewed and evaluated exactly in this context. Relations with the European countries of the socialist camp developed in an original way. The Soviet propaganda constantly spoke about friendly, fraternal relations. Information about the protests against the policies of the Communist Party and the Soviet government was concealed. The unrest that took place in the "humane, equitable" society was evaluated in the context of ideological confrontation as the machinations of the imperialists.

The collapse of the Soviet Union led to a shift of emphasis in the nature and content of historical researches in the newly independent states. First of all, it was possible to carry out a comparative analysis of the colonial policy of various empires including the Russian one. The next very important point was the radical change in the system of coordinates for the representatives of the post-Soviet states. It is one of the objective prerequisites of differences in the views of the researchers, their assessments, interpretation. Of course, historical science development in the Republic of Kazakhstan is no exception.

In the period of independence, scientists are more likely to refer to the subject which would seem to be sufficiently studied, i.e. the position of Kazakhstan in the Russian empire. The differences lie in the fact that historians are now moving away from the concepts that prevailed earlier while defining the place and the role of the peoples joined to Russia (the concepts of the relationship between "the older" and "the younger" brother, of "the lesser evil", etc.). Regardless of 
whether the former independent states have become its part voluntarily or have been annexed by force, the policy carried out is characterized as colonial.

With the collapse of the Soviet Union in all post-Soviet states there was a revaluation of values. Works by historians of the newly independent states are not always positively evaluated by their Russian counterparts. One of the reasons for disagreement is the inability to "separate" the political regime from the Fatherland, the colonial policy from the people whose representatives implemented this policy. Therefore, a negative assessment, for example, by the Kazakh historians of the colonial policy of the tsarist Russia is perceived by the Russian counterparts as the Russophobe views. In other cases it was the desire of the new political elites to place accents in their own by turning yesterday's villains into heroes.

In the Soviet times, the imperial policy of tsarism in the spiritual sphere was in the zone of silence. In school and high school history textbooks of that period more attention was paid to the development of the Russian capitalism gradually subjugating the economy of the Transcaucasian region, Central Asia and Kazakhstan. Russification policies and confessional protectionism against the peoples of the Kingdom of Poland, Finland and the Baltic states were mentioned in passing. A similar situation existed in the study of the processes of Russification and Christianization of the population of Kazakhstan; these topics were for the most part simply not considered. Only after the collapse of the Soviet Union publications on specific aspects of spiritual expansion of the Russian autocracy, including in Kazakhstan, began to appear.

The reasons for such state of affairs, in our opinion, first of all lie in the dominant ideology at the time, and the social sciences were given the passive role of "scientific" justification of the pre-defined ideologically verified conclusions. Ideological and geopolitical confrontation between the two world systems - socialism and imperialism - led to an uncompromising struggle in the sphere of social sciences. In these circumstances it is difficult to talk about objectivity and impartiality of historical research as to the forefront it is not the search for truth that comes but the desire to "prove" the point and the fallaciousness of views of the opponent that is of an ideological enemy in any way.

Works of the far abroad scholars are of particular interest. If in the Soviet times historians (regardless of their nationality) illustrate the actions of the Russian autocracy and its officials in the regions following the scheme of "liquidation of independence - the establishment of the Russian orders - colonial subjection", now such a sequence is considered mostly only by the non-Russian scientists. Meanwhile, such an order seems to be emerging in the relations developing between the Russian empire and Kazakhstan. Here, in our opinion, it is necessary to take into account the position of the German historian Jürgen Osterhammel (2000:223) who "formulated five policy principles" to be followed by the modern history of empires One of them states that "the study of the history of empires must take into account the views of those who had been colonized by these empires; it results in the appearance of the so-called "shared histories" («entangled or shared histories») (Randeria,2000:90). At the present stage the creation of the "shared history" causes certain difficulties. However, we must pay tribute to the individual works of the Russian historians which appeared in the years of perestroika and were distinguished by objective presentation of facts. Our task has more to do with discussing the status of the colonized non-Russian peoples.

\section{Research Method}

On the example of studying the policy of the Russian autocracy in the religious life of the non-Russian peoples the colonial character of the conducted activities is disclosed. The object of study are the works of the Soviet period and modern scientific publications devoted to the study of the colonial policy of the autocracy in the religious life of the nonRussian peoples.

While working on the article the authors used scientific methods of research. Currently researchers of the postSoviet republics are guided by the methodology of scientific knowledge which is free from previous directives imposed by the communist ideology. In the Soviet era bourgeois methodology was sharply criticized; according to the party ideologists it was unable to objectively reveal a particular scientific problem. The Soviet historians mostly completed their researches by "worthy" rebuff to the bourgeois "falsifiers of history". Completely different situation is developed today in relation to the foreign historians' researches. In this article we have also resorted to the publications of our colleagues from the yesterday's "enemy" camp that has enriched our joint work. The object and purpose of the study led to the choice of the used methods of scientific knowledge. Comparative analysis allowed us to make some conclusions, identifying the general and the particular characteristics of the policy of autocracy in the religious sphere of life of the nonRussian peoples. We used historical and logical methods, methods of comparison and generalization.

Summarizing it should be noted that the transformations that took place about a quarter of a century ago radically changed not only the map of the world, but also approaches to the study of the past. Historical researches of the Soviet 
and post-Soviet scholars differ. More differences are observed in the characterization of the policy of the Russian empire in the works of the Russian and non-Russian historians.

\section{Results and Discussion}

In this article we will focus on the main works of historians whose object of research was the policy of the Russian empire in the religious life of the non-Russian peoples in the XIX - early XX centuries.

In the Soviet era, religious issues and all that was connected with it including the activities of the religious ministers especially the Muslim ones who belonged to the exploiters in accordance with the scheme were assessed as obviously negative from the class positions. The main reason for the negative attitude towards religion was that it was considered as a counterweight to the communist ideology; hence the methods of dealing with religion. Closure of mosques, Orthodox and Catholic churches in the early years of the Soviet power occurred in most cases by force which resulted in the reduction in the number of believers visiting temples. This allowed the Soviet ideologists talk about great strides in atheistic education. In their turn the results obtained served as a material for writing anti-religious works which main aim was to promote liberation of the working people from the spiritual oppression of the traditional religion. Formation of atheistic consciousness was associated with economic, social and cultural changes. Religion was depicted as the drag of the social progress. Although historical experience convinces us rather of the opposite: there are numerous examples of successful development of countries with strong religious traditions.

Class approach put the Muslim religious ministers and the people on different sides of the barricades in a permanent struggle of the working people against the exploiters. All this resulted in the reactionary activities of servants of Islam. Ignorance, stupidity, hypocrisy of mullahs (as, indeed, of priests) were emphasized in every possible way. The book of T. Tazhibayev "Public education and schools of Kazakhstan in the second half of the XIX century" (Tazhibayev,1962:66) consisting of 507 pages is very indicative in this respect. Characteristics of schools with the new methodology which appearance was associated with Muslim leaders were devoted only half a page. It's natural that they were characterized negatively, other estimation from the class positions was simply impossible. According to the author "nationalists persistently preached schools with the new methodology but the latter did not meet the urgent demands of the people; they did not give students even basic foundations of scientific knowledge".

New approaches led to the appearance in the methodological arsenal of different concepts discussing the place and the role of civilization in the process of historical development. "Spiritual structure of civilization successfully plays the role of a keeper and a translator of historical memory and therefore it's devoted so much attention in the methodology of historical knowledge" (Kazakhstan in the XX century,1993:10).

Methodological flaw of the class approach is in the predetermination of estimates, their setting in advance: all that is connected with the exploiting classes is reactionary; all that comes from the working masses is progressive. Therefore, by the dogmatic version of the Marxist-Leninist theory it was assumed that "the contradictions were formulated in a very abstract and impersonal form: between production and consumption; productive forces and production relations... The main methodological orientation was to emphasize the unity of the parties" (Valikhanov,2003:57). One of the consequences of such an orientation is a method the essence of which has been set out by B. D. Grekov: "Written as well as non-written sources are at our service. But the source whatever it is may be useful only when the researcher himself/herself knows well what he/she wants from it" (Grekov,1975:21). This statement can be viewed in two ways. On the one hand, an authoritative historian could bear in mind the degree of "inclusion" of the researcher in the problem, on the other hand - predetermination, set course of source evaluation in accordance with existing ideological scheme. It is the last directive that became the reason that numerous works of the Soviet historians on the pre-formatted templates appeared over the years. Only materials that could confirm predetermined conclusions were specifically selected from a huge number of different sources. In other words: "History obeying it (the method - Z.S.,A.O.,A.S.) discovered just what it was expected to discover. Facts of the past were given a passive role of modern idea's demonstration" (Suleymenov,1975:173).

Antireligious propaganda was crucial in the education of the new Soviet man. Therefore works devoted to this problem had to show the harm of religion. The book by L. Klimovich "Islam in tsarist Russia" was published in 1936. Even a quick look at the book suggests us what readership it is intended for. Islam in this book is "an instrument of the Russian policy", "Muslim clergy" is the secret service of the Russian imperialism, "Pan-Islamists" are provocateurs playing the role of ideologue, etc. It is clear that these characteristics are supported by references. Jadidism characterized as "antirevolutionary trend" is given attention too (Klimovich,1936:307). For the Soviet ideologists the book by L. Klimovich was valuable because it helped propagandists keep atheistic conversation, meet with believers to explain the harm of religion. It served as an excellent material for the teachers of scientific atheism, for the history of the Communist Party of the 
Soviet Union and other social scientists.

Policy of the tsarist government on spreading Orthodoxy among the non-Russian peoples received coverage in the works of L. M. Dameshek $(1987 ; 1986)$ who investigated the region of Siberia in the period of tsarist reforms of the second half of the XIX century. In the course of the topic investigation the author is convinced of the marked evolution of the government policy in relation to the "aliens" from direct military "extermination" and "restraint" to the involvement of these peoples in the system of All-Russian public relations (Dameshek,1987:23). However, such an evolution could not and did not do good to people of other faiths. The monograph by L. M. Dameshek "Domestic policy of tsarizm and the peoples of Siberia in the XIX - early XX centuries" contains a number of provisions showing class bases of the unity of the Church and the state in trsarist Russia. The documents of the Bolshevik Party and the Soviet state, as well as the works of statesmen used by the author determined the ideological orientation of the study. It was appropriate, according to ideological workers, to use materials of the Collection of the Party's Documents emphasizing the right course of the CPSU. Thus, reference of the researcher to the resolution of the X Congress of the RCP (Russian Communist Party) (b) "About the immediate tasks of the Party in the national question" noting that the policy of tsarism "in relation to these peoples was to kill the rudiments of statehood among them, mutilate their culture, obstruct their languageto keep them in ignorance and finally, if possible, russify them" (Dameshek,1986:138) is a clear proof of that. To deny the resolution means to go against the truth. But the paradox is that this conclusion can be extended to the Soviet reality.

In the Soviet historiography relationship of the Russian and Kazakh population was treated solely as paternalistic and, therefore, as necessarily having a progressive character. Demonstrations against the Russian led by the Kazakh nobility during the period of colonization of the land could not be categorized as progressive movements. Therefore, in many works the movement under the leadership of the Kazakh sultan Kenessary Kassymov is classified as a reactionary one. Attempts of some Kazakh researchers to give an objective assessment of this movement entailed grave consequences for them, including long term imprisonment.

Thus, in the 50-s of the last century a young Kazakh historian E. Bekmakhanov was sentenced to 25-years imprisonment. For the sake of ideology, he emphasized the importance of friendly relations between the Russian and Kazakh people. But, in the opinion of the alert scientists from ideology, "the significance of joining Kazakhstan to Russia" was shown "with the bourgeois-nationalist positions; to justify his nationalist concept he used works of reactionary poets and enemies of the Soviet people - Alash Orda members" (Bekmakhanov,1992:396). The list of reactionary poets composed by Bolsheviks was supplemented those who pointed in their works to the negative consequences of Kazakhstan being a part of the Russian empire. They saw the Kazakh people suffering. They foresaw that the oppression in the spiritual life, namely Russification, Christianization, would lead to the loss of its originality. Akyns gave a sad name to this time: "Zar-zaman" - "The era of sorrow". The fighters for the independence of the Kazakh land, for the preservation of the nation became "nationalists". More advanced members of the Kazakh society trying to find ways of implementing the great goal that created the "Alash" party and the government of "Alash-Orda" became enemies of the people alashordyntsy. Most of them were killed during the repression years of 1937-1938.

In the 90-s of the XX century and at the beginning of the new millennium works which sharply differ from the previous ones appear. Freed from the Communist ideology, from the ideological pressure of the former system, historians got the opportunity to illuminate the past without embellishment, without fearing the consequences. There are the works in which the imperial policy of the Russian autocracy in Kazakhstan is considered not from the class positions but in terms of the national and spiritual oppression.

In Russia, they often began to address the problem of the religious expansion of tsarist Russia in the national borderlands. Though the expression "religious expansion" has not been made the name of research works by aspirants Z. A. Shagzhina (2001), V. K. Pinkevich (2002), Ye. A. Vishlenkova (1991), Yu. S. Belov (1999), D. Sh. Muftakhutdinova (1999), A. A. Ipatyeva (1999), E. I. Vorobyova (2000), T. V. Baturina (2000), it is mentioned in the content of their works.

These works show the Russian colonization, its progress, nature and results. The colonial policy of tsarism is subjected to critical analysis to identify the essential character of the Russian colonization, its historical specificity and at the same time similarities with the colonization of the New World by the European powers are shown. Policy of the Russian state on the Christianization of the non-Russian peoples, attitude towards the Muslim religion, other nonOrthodox faiths is traced.

Criticism of the autocracy reforms of the beginning of the XIX - early XX century in the religious sphere is also reflected in the works of these researchers. Elevating the status of the Russian Orthodox Church, the tsarist government hoped to consolidate its position on the eve of the two bourgeois revolutions. Naturally, other faiths and those who professed them were in constant oppression by the tandem of tsarism and the Russian Orthodox Church. Government policy is considered in conjunction with views about Islam and Muslims which existed and exist in Russia. 
Before and especially after the collapse of the Soviet Union, researchers of the CIS-countries and the Russian Federation, defend a great deal of candidate and doctoral dissertations containing the assessment (opposite to the Soviet one) of the role of the Russian culture and determination of the significance of its contribution to the cultural development of the non-Russian peoples. They show the activity of autocracy in alliance with the Russian Orthodox Church to enhance the spiritual influence on the non-Russian peoples. An objective approach of the research works' authors can be seen in the same characterization of persons directly participating in the public life of Russia. M. S. Korzun writes in his monograph (1984:187): "In the second half of the XIX century anti-national character of the Church and the Orthodoxy was expressed by Synod, chief prosecutors". The head of the Holy Synod is characterized as "an ideologist of greatpower chauvinism". The researcher quoted contemporary who wrote about the views of K. Pobedonostsev: "Fierce hostility hidden in the heart of any animal condemns to death all those of other religions, all which is able to claim the superiority" (Korzun,1984:175).

A common feature of these works is a negative evaluation of the colonial policy of tsarism in the regions of Russia; study of the influence of socio-economic transformations in Russia on the religious life of the non-Russian peoples; description of the methods of Christianization and Russification.

Works of researchers from far abroad dealing with the problems of the religious policy of tsarist Russia towards Islam attract attention. In 2001 the original English version of the book "Window to the East: empire, orientalism, nation and religion in Russia" of the American historian Robert Geraci came out (Geraci,2013:21). In 2013 its translation appeared. Huge work carried out by the author over the years has brought its effect. The author managed to highlight many questions concerning the Muslim and Orthodox religions, their ministers, education, activities of officials, and discontent of the native population about the pursued policy, missionary training and many other things. Robert Geraci writes about the status of the Tatar.

Regarding the religious policy of tsarist officials, the historian shows the activity aimed at the oppression of Islam and the Christianization of not only native people of the Middle Volga region but also of the border regions. Moreover, we share the assessment of Robert Geraci on a strong influence of the Tatar on the Kazakh. Indeed, acquaintance of the Russian with the Kazakh encouraged the former by the possibility to draw the nomads into the realm of Orthodoxy. Noting their indifference in religious issues they expected to increase easily the number of Christians. Over time, the situation changed not in favor of the preachers of Orthodoxy. The Tatars were to blame for that. The historian gives extracts from the leaf of the Brotherhood of St. Gury: "Mosques are springing up like poisonous mushrooms"; "In Central Asia the hope for the Christianization of the Kirgiz (Kazakh) became smaller as they "every year decisively and resolutely adjoin the Tatar-Mohammedans and increase their strength by half" (362). There were even fears that "the Muslim population in the Russian empire will become so numerous that it would cease to be predominantly Christian power"(Geraci,2013:362). In the final part of his work Robert Geraci wonders about the possible future of Russia,if the current policy of Russification and Christianization was successful. "What would become Russia in the end after it would change the "primitive" and "unenlightened" peoples of the East in its own image and likeness?" (Geraci,2013:430).

An assistant professor at Stanford University Robert Crews (2003) analyzes the relationship of tsarist power and the Muslim population of Russia in the XIX century in the article "Empire and confessional state: Islam and religious politics in nineteenth century in Russia". Geographically, the author raises the problem concerning the Muslim of European, south-east Russia and the Caucasus. However, confessional policy of the autocracy in relation to the nonChristians was almost the same. Comparing the legislative requirements for non-Orthodox denominations, the author emphasizes the connection between the religious orthodoxy and political loyalty. Officials of colonial administration controlled the appointment of religious leaders from the local elites who subsequently became conductors of the tsarist government's policy.

Colonization of the Kazakh lands by the Russian settlers affected the religious life of local and migrant residents. We cannot fully agree with the findings of some researchers who believe that despite the strong differences the Russian colonists and their descendants remained Russian preserving their language, customs and beliefs (Peopling the Russian,2007:62). Studying the documents of the state archives of St. Petersburg, Tashkent, Almaty, Omsk and rare collections' materials of the research libraries we came across the evidence of the influence of the native population on the Russian peasants and Cossacks as a result of which they became as if they became Kirgizs, Muslims, Basurmans.

The British researcher Stella Rock (2007) raises insufficiently studied problem of the "dual faith" and notes that this concept is a typical "scientific myth". If we stick to the viewpoint of the author who emphasizes the complex nature of folk beliefs and processes of Christianization of the medieval Russia, it should be noted that the belief in several gods took place even at a later time. It is confirmed by the revealed documentary materials. Thus, in the national borderlands of the Russian empire and also in Kazakhstan, in the course of drawing foreigners into the realm of Orthodoxy, there were cases of worshiping several gods. Christened foreigners in order to get benefits promised by the civil and ecclesiastical 
administration turned from their faith in Orthodoxy. In the afternoon they went to church, and at other times they appealed to their gods. That is why dual faith was common among the yesterday non-Christians.

\section{Conclusion}

Modern methodology of studying the religious life is different from the preceding one. In general, the Soviet historians avoided touching upon religious subjects. If there were single works they pursued one goal - to show religion in the darkest colors. Religious leaders and believers are backward personalities who are far from education, science, progress. Such an image appeared in the eyes of pioneers, Komsomol members, and the Soviet youth - the builders of communism. Only in the years of perestroika (1985-1990) in the Soviet Union they began to turn to religion. In 1988 the millennium of christening of Rus was celebrated, which surprised not only foreign countries, but also the population of the Soviet country.

Actually from that period warmer attitude to all religions started to appear. It was reflected in scientific researches. That is why scientific publications related to the state of religion in the past began to appear, the works of the so-called bourgeois scholars were studied.

Big splash occurred after the collapse of the Soviet empire. Infringement of language, religion, culture and everything national by the Russian tsarism - all these issues became the object of in-depth study of historians of the CIScountries and abroad. Process is going on but we need to do a lot to know all the pages of our history. And without place and role of religion in society it is difficult to restore and reconstruct the history of the people.

\section{References}

Osterhammel, J. (2000). Imperialgeschihte. Ch. Cornellisen (Hg). Geschihtwissenschaften. Eine Einfuhrung (pp.221-232). Frankfurt am Main. Randeria, Sh. (2000). Geteilte Geschichte und verwobene Moderne. J. Russen u.a. (Hg) Zukunfisentwurfe, Ideen fur eine Kultur der Veranderung (pp.87-96). Frankfurt am Main.

Tazhibayev T. (1962). Public education and schools of Kazakhstan in the second half of the XIX century. Alma-Ata:Kazgosizdat of political literature.

Kazakhstan in the XX century: methodology, historiography, source studies. (Collection of articles). Almaty.

Valikhanov, E. (2003). The research methodology of causal relationships of national liberation movements in the first half of the XIX century. Otan tarikhy, 1, 53-59.

Grekov, B.D. (1975). Kievan Rus. M.:Academy of Sciences of the USSR.

Suleymenov, O. (1975). AZ and Ya. Alma-Ata: Zhalyn.

Klimovich, L. (1936). Islam in tsarist Russia. Moscow.

Dameshek, L.M. (1987). Policy of the Russian autocracy against the peoples of Siberia in the era of capitalism (1861-1917): Abstract. dis. Dr. hist. sciences. Irkutsk.

Dameshek, L.M. (1986). Domestic policy of tsarizm and the peoples of Siberia in the XIX-early XX centuries. Irkutsk.

Bekmakhanov, E. (1992). Kazakhstan in 20-40-s of the XIX century. Alma-Ata: Kazakh University.

Shagzhina, Z.A. (2001). Missionary activity of the Russian Orthodox Church in the Transbaikal region (the second half of the XVII - the beginning of the $X X$ century): Abstract. dis. Dr. hist. sciences. Moscow.

Pinkevich, V.K. (2002). Religious reforms in Russia in the early XX century (1903 - February, 1917): Abstract. dis. cand. hist. sciences. Moscow.

Vishlenkova, Ye.A. (1999). Religious policy in Russia (the first quarter of the XIX century): Abstract. dis. Dr. hist. sciences. Moscow.

Belov, Yu.S. (1999). Government policy towards non-Orthodox faiths of Russia in 1905-1917: Abstract. dis. cand. hist. sciences. St. Petersburg.

Muftakhutdinova, D.Sh. (1999). The evolution of the Russian state policy towards the Muslim of the Volga and Ural regions (the second half of the XVII - the beginning of the XX century): Abstract. dis. cand. hist. sciences.Kazan.

Ipatyeva, A.A. (1999). Missionary activity of the Russian Orthodox Church in the south of the Far East region in the second half of the $X I X$ - early XX century: Abstract. dis. cand. hist. sciences. Krasnoyarsk.

Vorobyova, E.I.. (2000). Muslim question in the imperial policy of the Russian autocracy: the second half of the XIX century - 1917: Abstract. dis. cand. hist. sciences. - St. Petersburg.

Baturina, T. V. (2000). Russian Orthodox Church and the peasant settlers in Siberia at the turn of the XIX - XX centuries: Abstract. dis. cand. hist. sciences. Novosibirsk.

Korzun, M.S. (1984). Russian Orthodox Church in the service of the exploiting classes. X-1917. Minsk.

Geraci, R. (2013). Window to the East: empire, orientalism, nation and religion in Russia. Moscow.

Crews, R. (2003). Empire and confessional state: Islam and religious politics in nineteenth century in Russia. American Historical Review, 3, 34-50.

Peopling the Russian periphery Borderland colonization in Eurasian history (2007). In N. Breyfolge, A.Schrader, W. Sunderland (Ed.). N.Y: Routledge,.

Rock., S. (2007). Popular religion in Russia Double belief and the making of an academic myth. L.; N.Y.: Routledge. 